\title{
Silencing Smad4 attenuates sensitivity of colorectal cancer cells to cetuximab by promoting epithelial-mesenchymal transition
}

\author{
ZHENLV LIN $^{1}$, LIN ZHANG ${ }^{2}$, JUNFENG ZHOU ${ }^{2}$ and JIANTAO ZHENG ${ }^{2}$ \\ Departments of ${ }^{1}$ Surgical Emergency and ${ }^{2}$ Gastrointestinal Surgery, \\ The First Affiliated Hospital of Fujian Medical University, Fuzhou, Fujian 350005, P.R. China
}

Received July 26, 2018; Accepted April 4, 2019

DOI: $10.3892 / \mathrm{mmr} .2019 .10597$

\begin{abstract}
The aberrant expression of tumor suppressor Smad4 often occurs in colorectal cancer (CRC), and this phenomenon is believed to be associated with drug resistance. The present study aimed to investigate the effects of Smad4 on the sensitivity of CRC cells to cetuximab, and the possible mechanism underlying such an effect. A total of 629 colorectal adenocarcinoma cases were downloaded from The Cancer Genome Atlas (TCGA) database, and a Smad4 mutation rate of $21 \%$ was demonstrated among the cases. Low expression of Smad4 was present in CRC tissues analyzed by TCGA and in four CRC cell lines, as determined by reverse transcription-quantitative PCR (RT-qPCR) and western blot analysis. Cell Counting kit-8 (CCK-8) was used to measure the effects of different concentrations of cetuximab on SW480 cell viability at 24 and $48 \mathrm{~h}$. The results demonstrated that treatment of SW480 cells with $20 \mu \mathrm{g} / \mathrm{ml}$ cetuximab for $48 \mathrm{~h}$ markedly reduced cell viability. In addition, plasmids were transfected into SW480 cells to induce Smad4 silencing or overexpression. Silencing Smad4 attenuated the sensitivity of SW480 CRC cells to cetuximab; this effect was reflected in increased cell viability and slightly increased migration and invasion, as determined by CCK-8, wound scratch and Transwell analyses. RT-qPCR and western blotting was performed to assess the expression levels of apoptosis- and epithelial-mesenchymal transition (EMT)-related genes. Silencing Smad4 partly reversed the effects of cetuximab on the mRNA and protein expression levels of vimentin, Bax/Bcl-2 and E-cadherin. However, Smad4 overexpression enhanced SW480 cell sensitivity to cetuximab. In conclusion, Smad4 may serve a vital role in the sensitivity of CRC cells to chemotherapeutic drugs by promoting EMT.
\end{abstract}

Correspondence to: Dr Jiantao Zheng, Department of Gastrointestinal Surgery, The First Affiliated Hospital of Fujian Medical University, 20 Chazhong Road, Fuzhou, Fujian 350005, P.R. China

E-mail: jiantz_zhengjt@163.com

Key words: Smad4, colorectal cancer, epithelial-mesenchymal transition, cetuximab resistance

\section{Introduction}

Colorectal cancer (CRC) is one of the most common types of cancer worldwide, second to lung or breast cancer. In addition, $\mathrm{CRC}$ is the third most common type of cancer among men and the second among women worldwide. Annually, 30,000 new cases of CRC are identified and there are 90,000 cases of CRC-associated mortality globally (1). In addition, CRC is the third leading cause of morbidity and mortality among all malignant tumors in the United States (2). Despite continuing innovations in cancer treatment, the survival rate of patients with advanced CRC is low. The possibility of metastasis and recurrence is significantly increased once the tumor enters the middle and late stage, which is the main cause of mortality (3). In CRC, the 5-year survival rate for cancer in situ is $>65 \%$; however, the 5-year survival rate is between 25 and $60 \%$ if lymph node metastasis develops, and the 5-year survival rate remains $<7 \%$ once tumor cells have metastasized to distal organs (4). Conventional chemotherapeutic drugs, including irinotecan, oxaliplatin and fluorouracil, can improve the efficacy of metastatic CRC (mCRC) treatment; however, the median survival of patients remains $<2$ years $(5,6)$. The target epidermal growth factor receptor (EGFR) monoclonal antibody cetuximab, as a single drug therapy or as part of combination therapy, is the main method used to treat late mCRC (7). However, a number of patients are still resistant to cetuximab following treatment $(8,9)$.

The tumor suppressor gene Smad4 is an important transcriptional factor in the transforming growth factor $\beta$ signaling pathway. Gene aberration, including chromosome fragment loss, gene mutation and abnormal gene expression, often occurs in CRC and other gastrointestinal tumors (10-13). Smad4 is a member of the Smads protein family, and is located on chromosome 18q21 (14). Clinical studies have demonstrated that the risk of Smad4 deletion is increased in patients with advanced CRC with liver metastasis, and leads to poor prognosis (15-17). By contrast, the median survival time of CRC patients with high Smad4 expression is significantly longer compared with in those with low Smad4 expression (14).

Previous studies have demonstrated that tumor cells undergo epithelial-mesenchymal transition (EMT) with increased drug resistance $(18,19)$. EMT is a biological process in which epithelial cells gradually transform into cells with an interstitial phenotype through a specific procedure; this 
process may be involved in numerous biological behaviors, including wound healing and tumor metastasis (20-22). Its main characteristics are decreased cell adhesion molecule expression, transformation of the cytoskeleton from a cytokeratin to vimentin phenotype, and morphological characteristics of mesenchymal cells $(22,23)$. From classic morphological observations of $\mathrm{CRC}$, it has been identified that reversible morphological alterations occur during the process of tumor invasion and metastasis. Therefore, EMT is considered to serve an important role in CRC metastasis $(24,25)$.

Although several studies have reported that mutation or loss of Smad4 in CRC is closely associated with chemoresistance, these previous studies have mainly focused on conventional chemotherapeutic drugs, including 5-fluorouracil and oxaliplatin, and classic pathways including Akt and PI3K signaling (26-29). The present study aimed to investigate the effects of Smad4 on the sensitivity of CRC cells to cetuximab, which is an EGFR monoclonal antibody, and whether the effects were implicated in EMT.

\section{Materials and methods}

The Cancer Genome Atlas (TCGA) database analysis. A total of 629 colorectal adenocarcinoma cases were downloaded from TCGA database (http://www.cbioportal.org/). The mutations of Smad4, and the expression of Smad4 in CRC and matched normal tissues were analyzed.

Cell culture. Normal human colon epithelial cells (CCD 841 CoN cells) and four CRC cell lines (SW480, LoVo, SW620 and LS174T) were obtained from Invitrogen; Thermo Fisher Scientific, Inc. The cells were cultured in RPMI 1640 medium (Gibco; Thermo Fisher Scientific, Inc.) containing $10 \%$ fetal bovine serum (Gibco; Thermo Fisher Scientific, Inc.), $0.03 \%$ glutamine and $100 \mu \mathrm{g} / \mathrm{ml}$ streptomycin at $37^{\circ} \mathrm{C}$ in an incubator with $5 \% \mathrm{CO}_{2}$. The cells were digested and subcultured with $0.25 \%$ trypsin when confluence reached $80-90 \%$.

Cell transfection and grouping. The Smad4 silencing plasmid (siSmad4) (Forward: 5'-CGAAUACACCAACAAGUAATT-3', Reverse: 5'-UUACUUGUUGGUGUAUAUUCGTA-3'), Smad4 overexpression plasmid and empty control plasmid (negative control, NC) were purchased from Invitrogen; Thermo Fisher Scientific, Inc. SW480 cells were seeded in a 6 -well plate $\left(1.0 \times 10^{5}\right.$ cells /well) for $24 \mathrm{~h}$ before transfection and divided into three groups: i) the control (0.1\% PBS) subgroup, siNC subgroup, siSmad4 subgroup, NC subgroup and Smad4 overexpression plasmid subgroup; ii) the control (0.1\% PBS) subgroup, cetuximab (20 $\mu \mathrm{g} / \mathrm{ml}$; Merck KGaA) subgroup, $\mathrm{NC}+$ cetuximab $(20 \mu \mathrm{g} / \mathrm{ml})$ subgroup, siSmad4 + cetuximab $(20 \mu \mathrm{g} / \mathrm{ml})$ subgroup and siSmad4 subgroup; iii) the control (0.1\% PBS) subgroup, $\mathrm{NC}+$ cetuximab $(20 \mu \mathrm{g} / \mathrm{ml})$ subgroup and Smad4 overexpression plasmid + cetuximab $(20 \mu \mathrm{g} / \mathrm{ml})$ subgroup. Transient transfection was effected by Lipofectamine ${ }^{\circledR} 2000$ (Invitrogen; Thermo Fisher Scientific, Inc.) according to the manufacturer's protocol. A total of $20 \mu \mathrm{M}$ NC, siSmad4 or Smad4 overexpression plasmid, and $5 \mu$ l Lipofectamine ${ }^{\circledR} 2000$ were added to Opti-MEM and incubated at $25^{\circ} \mathrm{C}$ for $10 \mathrm{~min}$. Lipofectamine ${ }^{\circledR} 2000$ was then mixed into each well and the cells were cultured in Opti-MEM. After $6 \mathrm{~h}$ of culturing, the medium was replaced with RPMI-1640 containing 10\% FBS. After 24 h, the cells were used to perform the subsequent experiments.

Cell Counting kit-8 (CCK-8) viability assay. In the present study, the CCK- 8 assay was conducted in triplicate. Cells were plated into 96 -well plates at a seeding density of $1 \times 10^{4}$ cells/well for $24 \mathrm{~h}$. Initially, fresh medium containing $0.1,1,10,30,50$ or $100 \mu \mathrm{g} / \mathrm{ml}$ Cetuximab was used to treat the cells for 24 or $48 \mathrm{~h}$ at $37^{\circ} \mathrm{C}$, after which the CCK-8 assay was performed. In addition, the CCK- 8 assay was performed to explore the effects of silencing or overexpressing Smad4 on the viability of cetuximab-treated cells. Briefly, $10 \mu \mathrm{l}$ CCK-8 solution was added to the cells for $2 \mathrm{~h}$ at $37^{\circ} \mathrm{C}$. Optical density (OD) was measured at $450 \mathrm{~nm}$ (Thermo Fisher Scientific, Inc.).

Cell wound scratch assay. Cells were seeded in 6-well plates $\left(6 \times 10^{4}\right.$ cells/well) and incubated at $37^{\circ} \mathrm{C}$ for $24 \mathrm{~h}$. A sterile $100-\mu 1$ pipette tip was used to generate a wound in the center of the plate. PBS was used to gently wash the cells three times, and serum-free medium was added to the cells. Cell migration was observed using an inverted light microscope at $24 \mathrm{~h}$. The wound area was measured using ImageJ software version 1.49 (National Institutes of Health).

Cell invasion assay. Cell invasion was detected using a Matrigel-coated Transwell assay. Briefly, $100 \mu 1$ serum-free medium containing $10^{5}$ cells was added into the upper chamber (Corning, Inc.) and $600 \mu \mathrm{l}$ culture medium containing 10\% fetal bovine serum was added to the lower chamber. The cells were incubated for $24-48 \mathrm{~h}$ at $37^{\circ} \mathrm{C}$ in order to detect invasion into the lower membrane. Subsequently, the cells were fixed with $95 \%$ ethanol for $10 \mathrm{~min}$ at $25^{\circ} \mathrm{C}$ and stained with $0.5 \%$ crystal violet solution for $5 \mathrm{~min}$ at room temperature after the Matrigel on the filter membrane was removed.

Flow cytometry. Cell apoptosis was assessed by flow cytometry. Cells were harvested, collected and washed with cold PBS twice. The suspension $\left(5 \times 10^{5}\right.$ cells/well) in binding buffer was cultured with Annexin V-APC/7-AAD apoptosis kit [cat. no. AP105, Hangzhou Multi Sciences (Lianke) Biotech Co., Ltd.] in the dark at $25^{\circ} \mathrm{C}$ for $20 \mathrm{~min}$. Binding buffer was then added to each well and the samples were analyzed by flow cytometry within $1 \mathrm{~h}$ using BD CellQuest Pro Software version 1.2; BD Biosciences).

Reverse transcription-quantitative PCR (RT-qPCR). Smad4, apoptosis-related genes (Bax and $\mathrm{Bcl}-2$ ), E-cadherin and vimentin were detected by RT-qPCR in the different groups. Total RNA was extracted from cultured cells using TRIzol ${ }^{\circledR}$ (Invitrogen; Thermo Fisher Scientific, Inc.) according to the manufacturer's protocol. Total RNA was reverse transcribed with the PrimeScript ${ }^{\mathrm{TM}}$ RT reagent kit (Takara Bio, Inc.) at $37^{\circ} \mathrm{C}$ for $45 \mathrm{~min}$ and then at $85^{\circ} \mathrm{C}$ for $5 \mathrm{~min}$. cDNA was amplified using SYBR Fast qPCR Mix (Invitrogen; Thermo Fisher Scientific, Inc.). For quantitative real-time PCR, the PCR reaction was set at $95^{\circ} \mathrm{C}$ for $5 \mathrm{~min}$, followed by 33 cycles at $94^{\circ} \mathrm{C}$ for $30 \mathrm{sec}, 55^{\circ} \mathrm{C}$ for $30 \mathrm{sec}, 72^{\circ} \mathrm{C}$ for $45 \mathrm{sec}$ and $72^{\circ} \mathrm{C}$ extension for $10 \mathrm{~min}$. The primer sequences used are listed in Table I. 
Table I. Primers used in reverse transcription-quantitative PCR.

\begin{tabular}{ll}
\hline Gene & \multicolumn{2}{c}{ Sequence } \\
\hline Smad4 & F: 5'-CTGAACTGTTTGTACCTCTGGGCC \\
& ATATTGC-3' \\
& R:5'-CAAATTCTGAAGAGTAGGTGATC \\
& CGGGTGGAG-3' \\
Bcl-2 & F: 5'-ATGGCGCACGCTGGGAGAAC-3' \\
& R:5'-CTGGCGGAGGGTCAGGTGGA-3' \\
Bax & F: 5'-GCCGCCGTGGACACAGACTC-3' \\
& R:5'-CCGCTCCCGGAGGAAGTCCA-3' \\
E-cadherin & F: 5'-ATCCAAAGCCTCAGGTCATA-3' \\
& R:5'-CAGCAAGAGCAGCAGAAT-3' \\
Vimentin & F: 5'-GAACTTTGCCGTTGAAGCTG-3' \\
& R:5'-TCTCAATGTCAAGGGCCATC-3' \\
GAPDH & F: 5'-ACCACAGTCCATGCCATCAC-3' \\
& R:5'-TCCACCACCCTGTTGCTGTA-3'
\end{tabular}

$F$, forward; R, reverse.

mRNA expression was quantified using the $2^{-\Delta \Delta \mathrm{Cq}}$ method (30). GAPDH served as an internal control.

Western blotting. Total protein was extracted from cultured cells using lysis buffer; RIPA buffer (Thermo Fisher Scientific, Inc.) was added to each well and cells were centrifuged at $14,000 \mathrm{x} \mathrm{g}$ for $15 \mathrm{~min}$ at $4^{\circ} \mathrm{C}$. Bicinchoninic acid protein quantification (Thermo Fisher Scientific, Inc.) was used to detect protein concentration. Proteins $(20 \mu \mathrm{g} / \mathrm{lane})$ were separated by $10 \%$ SDS-PAGE and were then transferred onto polyvinylidene difluoride membranes, which were blocked in TBS- $0.1 \%$ Tween-20 (TBST) containing $1 \%$ milk at room temperature for $2 \mathrm{~h}$. The membranes were then incubated with the following primary antibodies: Rabbit anti-Smad4 (cat. no. ab40759, 1:5,000; Abcam), anti-Bcl-2 (cat. no. ab182858, 1:2,000; Abcam), anti-Bax (cat. no. ab32503, 1:1,500; Abcam), mouse anti- E-cadherin (cat. no. ab1416, 1:50; Abcam), anti-vimentin (cat. no. ab8978, 1:1,000; Abcam) and anti-GAPDH (cat. no. ab8245, 1:1,000; Abcam). The membranes were washed with TBST, and were then incubated with horseradish peroxidase-conjugated goat anti-rabbit immunoglobulin G (1:2,000; SA00001-2; ProteinTech Group, Inc.) and with horseradish peroxidase -conjugated goat anti-mouse IgG (1:2,000; sc-516102; Santa Cruz Biotechnology, Inc.) as secondary antibodies. The blots were visualized by enhanced chemiluminescence (ECL; Thermo Fisher Scientific, Inc.). An ECL system (Amersham; GE Healthcare) was used to detect the bands. The density of the blots was measured using Quantity One software version 2.4 (Bio-Rad Laboratories, Inc.).

Statistical analysis. Statistical analysis was performed using Prism GraphPad version 6.0 software (GraphPad Software, Inc.). All data are presented as the means \pm standard deviation. Differences were analyzed using one-way analysis of variance following Tukey's multiple comparison post hoc test. $\mathrm{P}<0.05$ was considered to indicate a statistically significant difference.

\section{Results}

Low expression of Smad4 in CRC tissues and CRC cell lines. TCGA data (Fig. 1A and B) demonstrated that Smad4 was mutated in $131(21 \%)$ out of 629 sequenced cases/patients with colorectal adenocarcinoma. The majority of the mutations were deletions. In addition, mRNA and protein expression levels of Smad4 in cancer tissues were lower than those in normal tissues in the cases downloaded from TCGA (Fig. 1C). The expression levels of Smad4 in normal colonic epithelial cells and four CRC cell lines were determined by RT-qPCR and western blot analysis. The results demonstrated that expression of Smad4 in CRC cell lines (SW480, LoVo, SW620 and LS174T) was significantly decreased compared with in CCD 841 CoN cells at the mRNA and protein levels $(\mathrm{P}<0.01$; Fig. 1D and E). The SW480 cell line was selected as the subject of subsequent experiments as it had the lowest expression of Smad4 at the mRNA and protein levels.

Silencing Smad4 attenuates cell sensitivity to cetuximab in SW480 CR C cells. SW480 cells were treated with or without different concentrations $(0.1,1,10,30,50$ and $100 \mu \mathrm{g} / \mathrm{ml})$ of cetuximab. There was a difference in OD $450 \mathrm{~nm}$ with $0 \mu \mathrm{g} / \mathrm{ml}$ Cetuximab since the cells proliferated after 24 and $48 \mathrm{~h}$. Cell viability was increased in response to treatment with different concentrations of cetuximab for 24 and $48 \mathrm{~h}$ compared to $0 \mathrm{~h}(\mathrm{P}<0.05$; Fig. 2A). The results indicated that certain cells already had drug resistance, and therefore, the inhibitory effect of cetuximab was not significant at $24 \mathrm{~h}$. However, at $48 \mathrm{~h}$, cell viability was downregulated in a dose-dependent manner until the cells were treated with $20 \mu \mathrm{g} / \mathrm{ml}$ cetuximab. Therefore, $20 \mu \mathrm{g} / \mathrm{ml}$ cetuximab (48 h) was selected as an effective concentration in subsequent experiments. The transfection efficiency of siSmad4 was demonstrated in Fig. 2B and C; the expression levels of Smad4 were significantly decreased post-transfection with siSmad4. In addition, treatment with $20 \mu \mathrm{g} / \mathrm{ml}$ cetuximab $(\mathrm{P}<0.05)$ or siSmad4 $(\mathrm{P}<0.01)$ significantly inhibited Smad4 protein (Fig. 2D) and mRNA (Fig. 2E) expression. When cetuximab was used in combination with siSmad4, the inhibitory effect on Smad4 expression was at its most significant $(\mathrm{P}<0.01)$. Furthermore, cetuximab treatment alone and $\mathrm{NC}+$ cetuximab markedly downregulated SW480 cell viability $(\mathrm{P}<0.01$; Fig. $2 \mathrm{~F})$. However, the effect of cetuximab treatment was clearly inhibited when cetuximab was used in combination with siSmad4, compared with single cetuximab or $\mathrm{NC}+$ cetuximab $(\mathrm{P}<0.01)$. In addition, compared with groups treated with cetuximab, siSmad4 alone significantly enhanced cell viability $(\mathrm{P}<0.01)$. Silencing Smad4 not only increased SW480 cell viability, but also partly reversed the cell viability decrease induced by cetuximab, indicating that silencing Smad4 may attenuate cell sensitivity to cetuximab in the SW480 CRC cell line.

Silencing Smad4 partly reverses the decrease in cell migration and invasion, and the increase in cell apoptosis induced by cetuximab. Cell migration was detected using a scratch assay. The results revealed that cetuximab and $\mathrm{NC}+$ cetuximab 
A

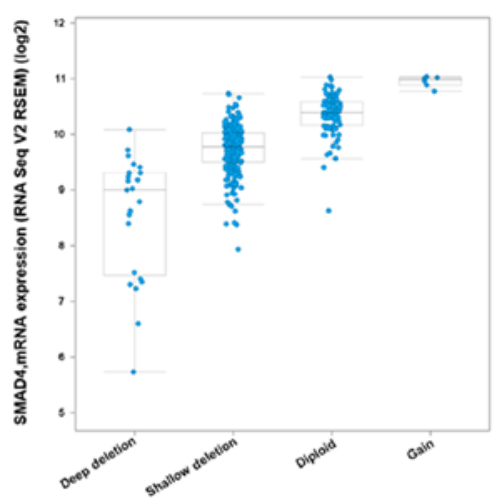

B

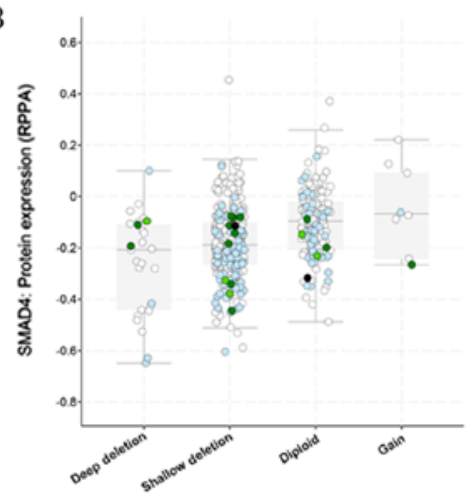

C

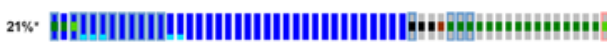

Genetic Alteration

\section{2.}

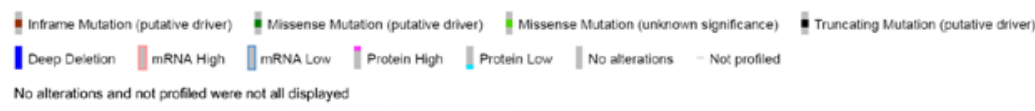

$\mathrm{D}$ Relative expression of SMAD4 protein/GAPDH

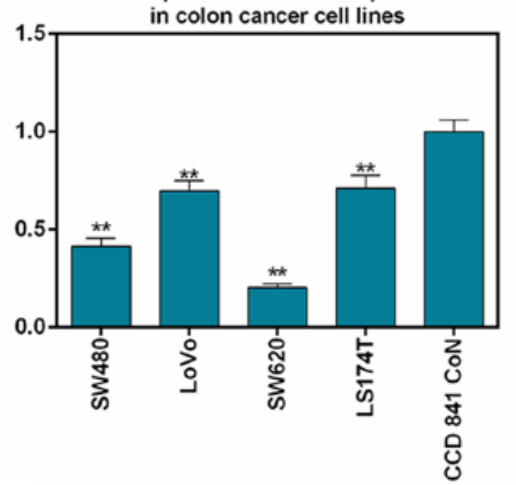

E

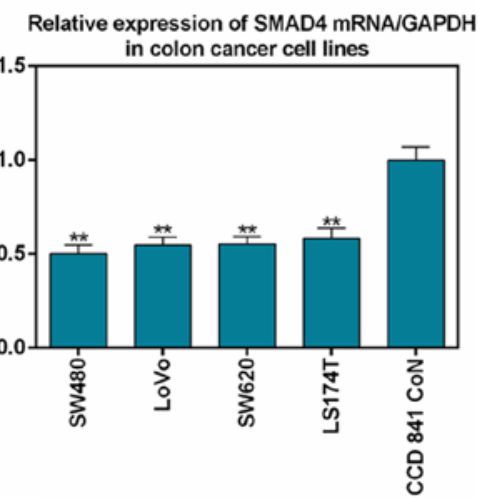

SMAD4

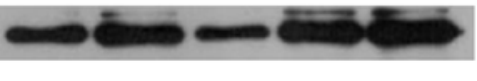

GAPDH

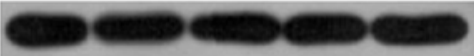

Figure 1. mRNA and protein expression levels of Smad4 in samples from patients with CRC and several cell lines. (A) The Cancer Genome Atlas database analysis of Smad4 mRNA sequences in 629 patients with CRC. (B) The Cancer Genome Atlas database analysis of Smad4 protein sequences in patients with CRC. (C) The Cancer Genome Atlas database analysis of Smad4 on Genetic alteration. (D) Protein expression levels of Smad4 in colonic epithelial cells and CRC cell lines were detected using western blotting. (E) mRNA expression levels of Smad4 in normal colonic epithelial cells (CCD 841 CoN cells) and CRC cell lines (SW480, LoVo, SW620 and LS174T) were detected by reverse transcription-quantitative polymerase chain reaction. GAPDH was used as an internal control. ${ }^{* *} \mathrm{P}<0.01$ vs. normal colonic epithelial cells. CRC, colorectal cancer.

treatment significantly increased the open wound area, compared with the control ( $\mathrm{P}<0.01$; Fig. 3A). Silencing Smand4 markedly reduced the open wound area $(\mathrm{P}<0.01$; Fig. $3 \mathrm{~A})$. The open wound area was decreased by siSmad 4 in combination with cetuximab compared with siSmad4 treatment alone; however, the decreased effect was not significant compared with cetuximab or cetuximab + NC. A Transwell assay was used to determine cell invasion and the result demonstrated that the invasion rate of SW480 cells was markedly decreased in groups treated with cetuximab $(\mathrm{P}<0.01$; Fig. 3B). Conversely, invasion of cells transfected with siSmad4 was significantly increased $(\mathrm{P}<0.01$; Fig. 3B). However, silencing Smad4 only partly increased the cell invasion attenuated by cetuximab. The effects of silencing Smad4 on the apoptosis of SW480 cells with or without cetuximab were detected by flow cytometric analysis. A noticeable increase in apoptosis $(\mathrm{P}<0.01$; Fig. $3 \mathrm{C})$ was identified in the cetuximab (17.47\%), NC + cetuximab $(18.4 \%)$ and siSmad4 + cetuximab $(9.18 \%)$ groups, compared with in the control group (4.48\%). Silencing Smad4 (4.17\%) significantly downregulated apoptosis rate $(\mathrm{P}<0.01)$ compared with in the cetuximab $(17.47 \%)$ or siSmad4 + cetuximab (9.18\%) groups. In addition, silencing Smad4 partly reversed the increase in cell apoptosis induced by cetuximab $(\mathrm{P}<0.01)$.

Effects of silencing Smad4 on apoptosis- and EMT-related gene expression in SW480 cells with or without cetuximab treatment. The expression levels of the apoptosis-related genes Bax and Bcl-2 were detected by RT-qPCR and western blot analysis. The results also demonstrated that cetuximab downregulated $\mathrm{Bcl}-2(\mathrm{P}<0.01$; Fig. $4 \mathrm{~A}, \mathrm{~B}$ and $\mathrm{F})$ and upregulated Bax protein $(\mathrm{P}<0.01$; Fig. $4 \mathrm{~A}$ and $\mathrm{C})$ and $\mathrm{mRNA}$ expression $(\mathrm{P}<0.01$; Fig. 4G) compared with control. Silencing Smad4 partly reversed the decreased expression of $\mathrm{Bcl}-2$ and the increased expression of Bax (protein, $\mathrm{P}<0.01$ ) by cetuximab. Silencing Smad4 treatment alone could attenuate Bax expression in comparison with siSmad4 + cetuximab (protein, $\mathrm{P}<0.05$; mRNA, $\mathrm{P}<0.01$ ). To further determine how silencing Smad4 could affect EMT in SW480 CRC cells with or without cetuximab treatment, the expression of EMT-associated genes (E-cadherin and vimentin) was detected using RT-qPCR 
A

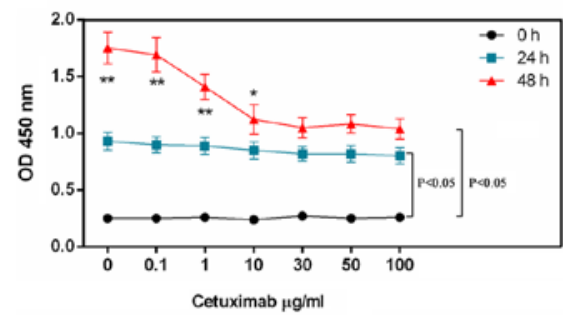

D

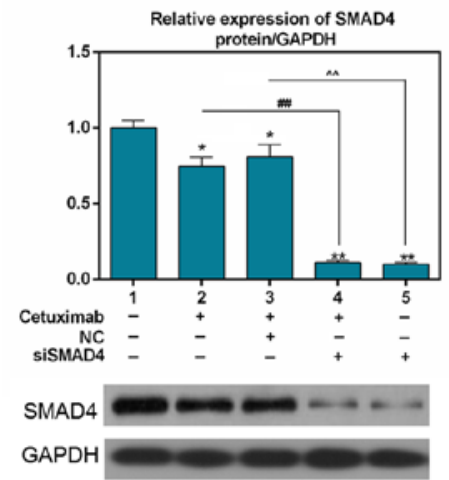

B

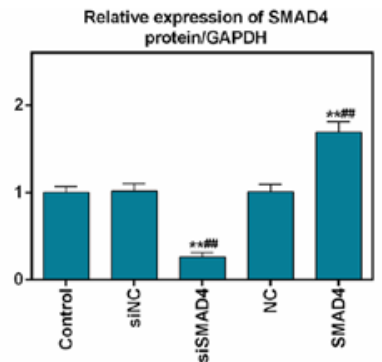

SMAD4

GAPDH

E

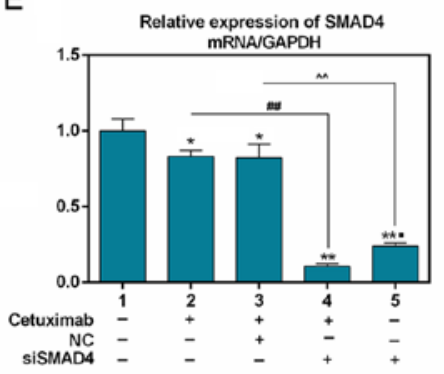

C

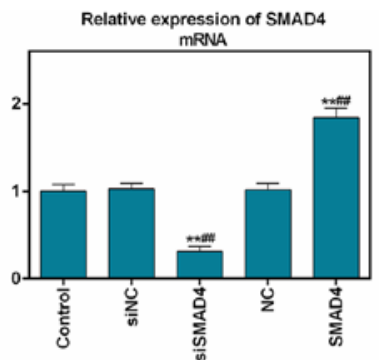

$\mathrm{F}$

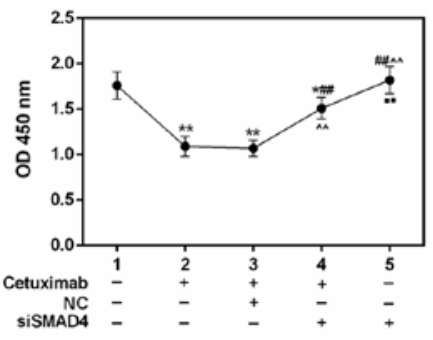

Figure 2. mRNA and protein expression levels of Smad4, and cell viability analysis in SW480 colorectal cancer cells with or without cetuximab treatment. (A) Different concentrations $(0.1,1,10,30,50$ and $100 \mu \mathrm{g} / \mathrm{ml})$ of cetuximab were used to treat SW480 cells for 0,24 or $48 \mathrm{~h}$, and cell viability was detected by CCK-8 assay. ${ }^{*} \mathrm{P}<0.05$ and ${ }^{* *} \mathrm{P}<0.01$ vs. 0 h. (B) Protein expression levels of Smad4 were assessed post-transfection with plasmids silencing or overexpressing Smad4 by western blotting in SW480 cells. (C) mRNA expression levels of Smad4 in SW480 cells post-transfection with plasmids silencing and overexpressing Smad4 by reverse transcription-quantitative PCR. GAPDH served as an internal control. Data are expressed as the means \pm standard deviation from three independent experiments. ${ }^{* *} \mathrm{P}<0.01$ vs. control; ${ }^{\# \#} \mathrm{P}<0.01$ vs. NC. (D) Protein expression levels of Smad4 were assessed post-transfection with a plasmid silencing Smad4 using western blot analysis in SW480 cells. ${ }^{*} \mathrm{P}<0.05$ and ${ }^{* * *} \mathrm{P}<0.01$ vs. control; ${ }^{\# \#} \mathrm{P}<0.01$ vs. cetuximab; ${ }^{\wedge} \mathrm{P}<0.01$ vs. NC + cetuximab. (E) mRNA expression levels of Smad4 were assessed post-transfection by reverse transcription-quantitative PCR in SW480 cells. GAPDH served as an internal control. (F) Viability of SW480 CRC cells was assessed by CCK-8 assay after $48 \mathrm{~h}$. Data are expressed as the means \pm standard deviation from three independent experiments. ${ }^{*} \mathrm{P}<0.05$ and ${ }^{* *} \mathrm{P}<0.01$ vs. control; ${ }^{\mathrm{P}} \mathrm{P}<0.05$ and ${ }^{-\mathrm{P}} \mathrm{P}<0.01$ vs. siSmad4 + cetuximab; ${ }^{\# \#} \mathrm{P}<0.01$ vs. cetuximab; ${ }^{\wedge} \mathrm{P}<0.01$ vs. NC + cetuximab. CCK-8, Cell Counting kit-8; CRC, colorectal cancer; NC, negative control; OD, optical density; siSmad4, small interfering RNA-Smad4.
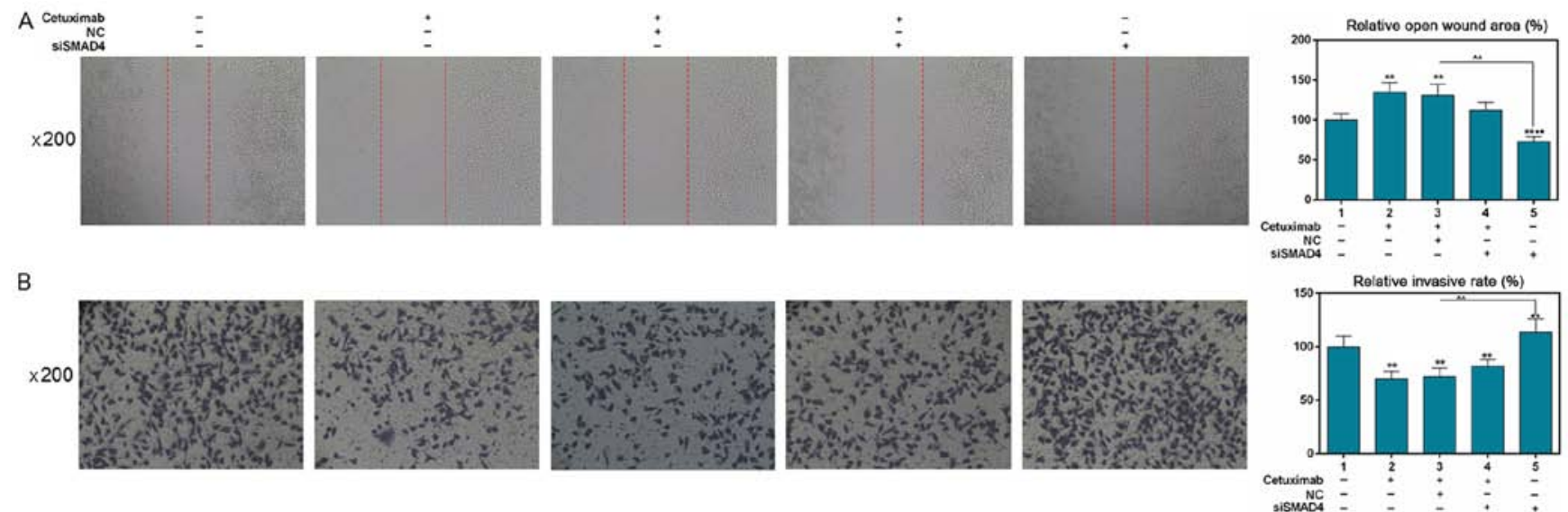

C
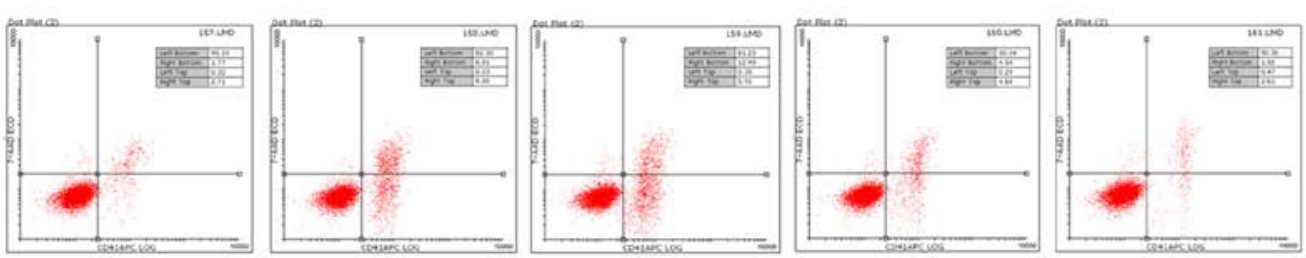

Figure 3. siSmad4 affects cell migration, invasion and apoptosis of SW480 cells with or without cetuximab treatment. (A) Cell migration was detected using a scratch assay, (x200 magnification; light microscopy). (B) Transwell assay was used to determine cell invasion (x200 magnification; light microscopy). (C) Apoptosis was detected by flow cytometry. ${ }^{* *} \mathrm{P}<0.01$ vs. control; ${ }^{-P} \mathrm{P}<0.01$ vs. siSmad $4+$ cetuximab; ${ }^{\# \#} \mathrm{P}<0.01 \mathrm{vs}$. cetuximab; ${ }^{\wedge} \mathrm{P}<0.01 \mathrm{vs}$. NC + cetuximab. NC, negative control; siSmad4, small interfering RNA-Smad4. 

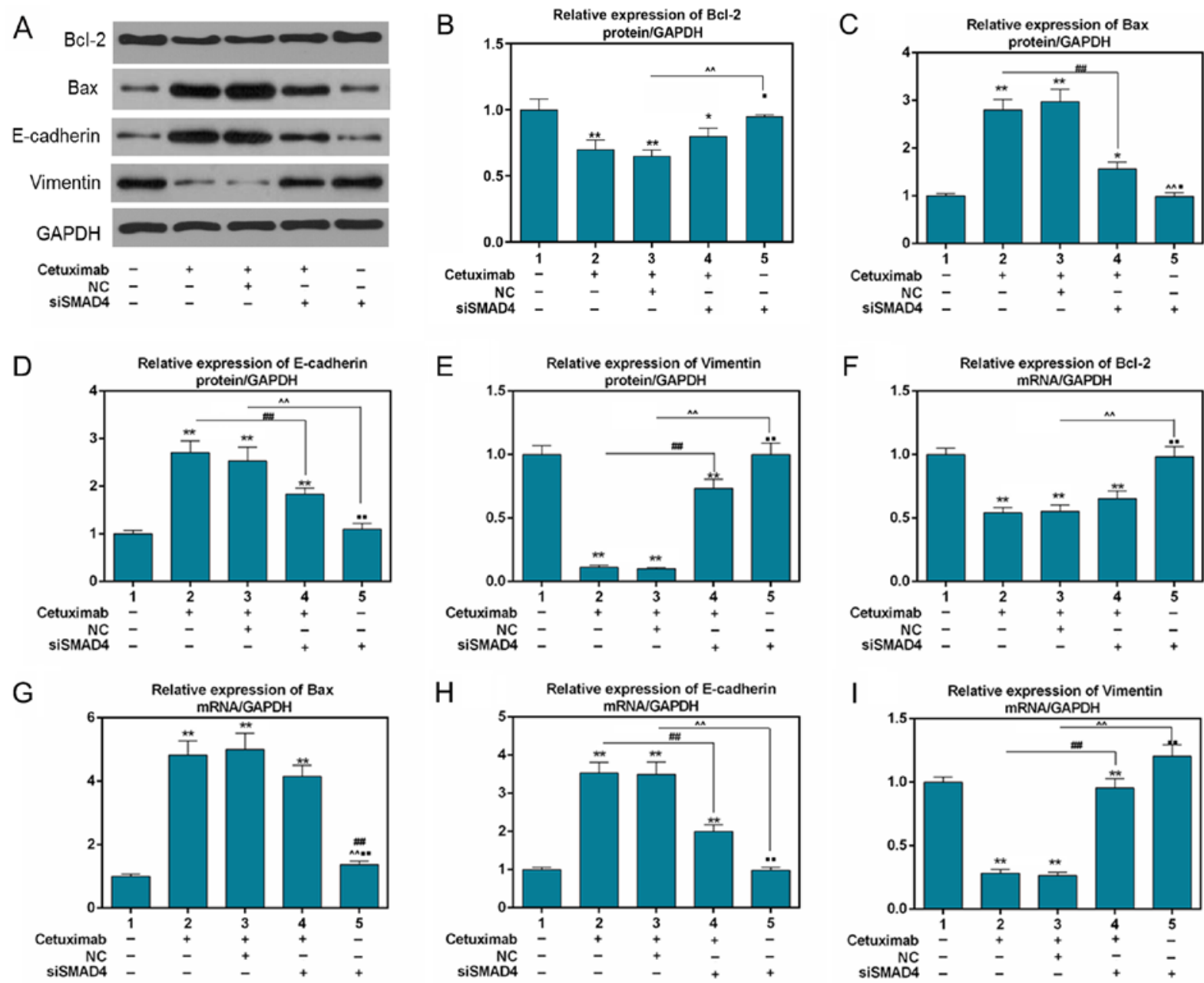

Figure 4. Silencing Smad4 affects the expression of apoptosis-and epithelial-mesenchymal transition-associated genes in SW480 cells with or without cetuximab treatment. (A) Protein expression levels of Bcl-2, Bax, E-cadherin and vimentin were assessed using western blot analysis in SW480 cells with or without cetuximab treatment. Relative protein levels of (B) Bcl-2, (C) Bax, (D) E-cadherin and (E) vimentin were presented as histograms. mRNA expression levels of (F) Bcl-2, (G) Bax, (H) E-cadherin and (I) vimentin were assessed using reverse transcription-quantitative PCR in SW480 cells with or without cetuximab treatment. GAPDH served as an internal control. Data are expressed as the means \pm standard deviation from three independent experiments. ${ }^{*} \mathrm{P}<0.05$ and ${ }^{* *} \mathrm{P}<0.01$ vs. control; ${ }^{-\mathrm{P}}<0.05$ and ${ }^{-\mathrm{P}} \mathrm{P}<0.01$ vs. siSmad4 + cetuximab; ${ }^{\# \#} \mathrm{P}<0.01$ vs. cetuximab; ${ }^{\wedge} \mathrm{P}<0.01$ vs. NC + cetuximab. NC, negative control; siSmad4, small interfering RNA-Smad4.

and western blot analysis. The results demonstrated that both protein (Fig. 4A and D) and mRNA levels (Fig. 4H) of E-cadherin were increased in the cetuximab and $\mathrm{NC}+$ cetuximab groups compared with in the control group $(\mathrm{P}<0.01)$. Conversely, the mRNA and protein expression levels of E-cadherin were significantly downregulated in the siSmad4 and siSmad 4 + cetuximab groups compared with in the cetuximab or $\mathrm{NC}+$ cetuximab groups $(\mathrm{P}<0.01)$. The effects of siSmad4 on vimentin expression demonstrated opposite results to those on E-cadherin at the mRNA and protein levels ( $\mathrm{P}<0.01$; Fig. 4A, E and I). These results indicated that silencing Smad4 partly reversed the effects of cetuximab on the expression of apoptosis- and EMT-related genes.

Overexpression of Smad4 enhances the sensitivity of SW480 cells to cetuximab. The transfection efficiency of the Smad4 overexpression plasmid was demonstrated in Fig. 2B and C; Smad4 expression was significantly increased post-transfection with the overexpression plasmid. As shown in Fig. 5A-C, cetuximab significantly inhibited Smad4 protein $(\mathrm{P}<0.05)$ and mRNA expression $(\mathrm{P}<0.01)$. Smad4 overexpression partly reversed the expression of Smad4 decreased by cetuximab $(\mathrm{P}<0.01)$. Cell viability was detected using the CCK-8 assay; the results demonstrated that $\mathrm{NC}+$ cetuximab significantly decreased cell viability $(\mathrm{P}<0.01$; Fig. 5D). Cetuximab in combination with Smad4 overexpression further decreased cell viability compared with the control group $(\mathrm{P}<0.01)$. In addition, cell viability was attenuated in the Smad4 overexpression + cetuximab group compared with in the $\mathrm{NC}+$ cetuximab group $(\mathrm{P}<0.05)$, suggesting that overexpressing Smad4 may enhance the sensitivity of SW480 cells to cetuximab.

Overexpression of Smad4 enhances the effects of cetuximab on invasion, migration and apoptosis of SW480 cells. As shown in Fig. 6A, NC + cetuximab slightly increased the wound area compared with in the control group $(\mathrm{P}<0.05)$. Overexpression of Smad4 had no evident effect on the inhibition of migration induced by cetuximab $(\mathrm{P}>0.05)$. The Transwell assay demonstrated that $\mathrm{NC}+$ cetuximab and Smad4 overexpression + cetuximab significantly downregulated invasion rate $(\mathrm{P}<0.01$; Fig. 6B). For cell apoptosis, the results demonstrated that cetuximab treatment alone (18.79\%), and also Smad4 
A

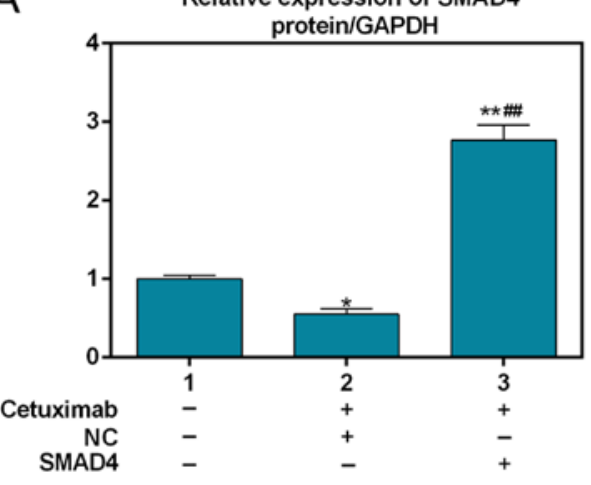

B

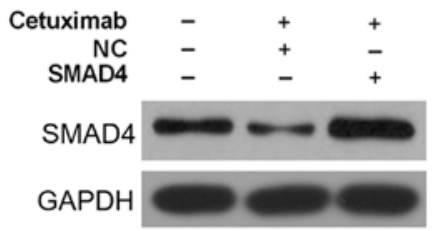

C
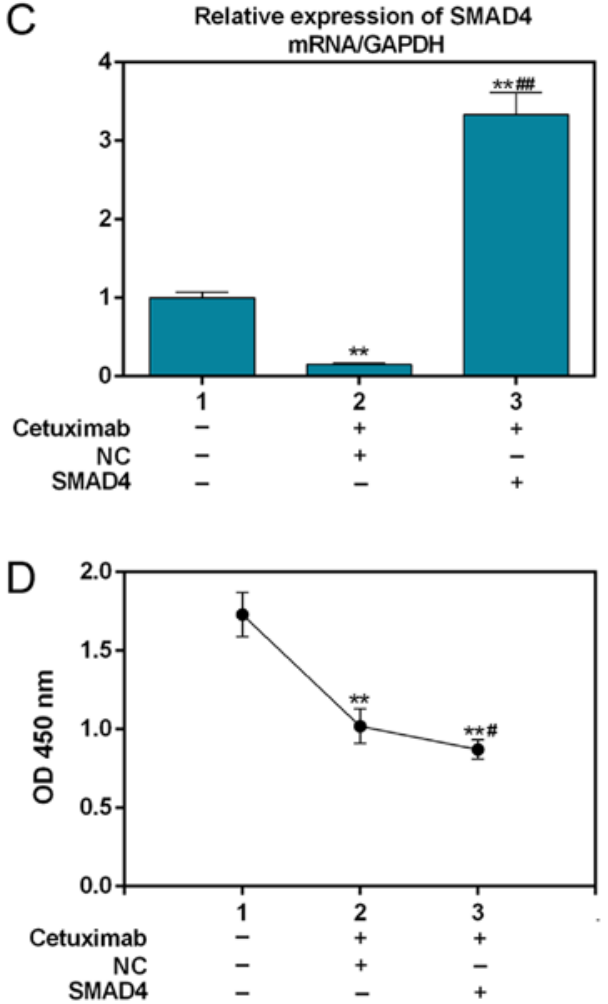

Figure 5. mRNA and protein expression levels of Smad4, and cell viability analysis of SW480 cells overexpressing Smad4 and treated with cetuximab. (A and B) Protein expression levels of Smad4 were detected by western blotting and presented as histograms. (C) mRNA expression levels of Smad4 were assessed by reverse transcription-quantitative PCR; GAPDH served as an internal control. (D) Effects of Smad4 overexpression on the viability of SW480 colorectal cancer cells treated with cetuximab was assessed by the Cell Counting kit- 8 assay after $48 \mathrm{~h}$. Data are expressed as the means \pm standard deviation from three independent experiments. ${ }^{*} \mathrm{P}<0.05$ and ${ }^{* *} \mathrm{P}<0.01$ vs. control; ${ }^{\#} \mathrm{P}<0.05$ and ${ }^{\# \#} \mathrm{P}<0.01$ vs. NC + cetuximab. NC, negative control; OD, optical density; siSmad4, small interfering RNA-Smad4.

overexpression + cetuximab (25.25\%) significantly upregulated the apoptosis rate compared with in the control group (4.64\%, P<0.01; Fig. 6C). Additionally, the apoptotic effect of Smad4 overexpression + cetuximab was significantly different compared with treatment with cetuximab alone $(\mathrm{P}<0.01)$.

\section{Effects of Smad4 overexpression on apoptosis-and EMT-related} gene expression in SW480 cells treated with cetuximab. The results revealed that the anti-apoptosis gene Bcl-2 was markedly decreased in the Smad4 overexpression + cetuximab group compared with in the control and $\mathrm{NC}+$ cetuximab groups, at the mRNA and protein levels $(\mathrm{P}<0.01$; Fig. $7 \mathrm{~A}, \mathrm{~B}$ and $\mathrm{F})$. At the protein level, the expression of Bax was significantly increased in the Smad4 overexpression + cetuximab and $\mathrm{NC}+$ cetuximab groups compared with in the control group $(\mathrm{P}<0.01$; Fig. $7 \mathrm{~A}$ and C). Notably, the increase in Bax expression was more noticeable in the Smad4 overexpression + cetuximab group compared with in the $\mathrm{NC}+$ cetuximab group. The effects of treatments on the mRNA expression levels of Bax were consistent with those on protein expression $(\mathrm{P}<0.01$; Fig. $7 \mathrm{G})$. Furthermore, the protein and mRNA expression levels of E-cadherin were significantly upregulated in the Smad4 overexpression + cetuximab group compared with in the control and $\mathrm{NC}+$ cetuximab groups $(\mathrm{P}<0.01$; Fig. 7A, D and H). Conversely, the protein expression levels of vimentin were significantly decreased in the Smad4 overexpression + cetuximab group compared with in the control and $\mathrm{NC}+$ cetuximab groups $(\mathrm{P}<0.01$; Fig. $7 \mathrm{~A}$ and $\mathrm{E})$. At the mRNA level, the Smad4 overexpression + cetuximab group exhibited no clear difference in vimentin expression compared with the $\mathrm{NC}+$ cetuximab group ( $\mathrm{P}>0.05$; Fig. 7I). However, the mRNA expression levels of vimentin were markedly downregulated compared with in the control group $(\mathrm{P}<0.01$; Fig. 7I).

\section{Discussion}

Smad4 is absent or mutated in numerous tumor types, including pancreatic, colon, gastric and liver cancer, and particularly in digestive system tumors. Therefore, it is thought to function as a tumor suppressor gene (31-34). One of the major causes of CRC progression is chromosomal instability, including APC, p53 and DCC/Smad4 deficiency (35-37). Therefore, the roles of Smad 4 cannot be neglected in the development of CRC $(38,39)$. Surgery is the main method for treating early CRC; however, recurrence and metastasis often occur following surgery. With the increasing use of adjuvant therapy using chemicals such as cetuximab, drug resistance of tumor cells is a pivotal cause of poor prognosis among patients with CRC (6).

The present study revealed that cetuximab treatment alone inhibited SW480 cell viability, migration and invasion, and promoted cell apoptosis. Although Mei et al (40) reported that Smad4 and neurofibromin 1 mutations may be potential biomarkers for poor responses to cetuximab-based therapy, related molecular mechanisms have not been studied. The present study suggested that silencing Smad4 in combination with cetuximab treatment enhanced SW480 cell viability, migration and invasion, and inhibited cell apoptosis. 

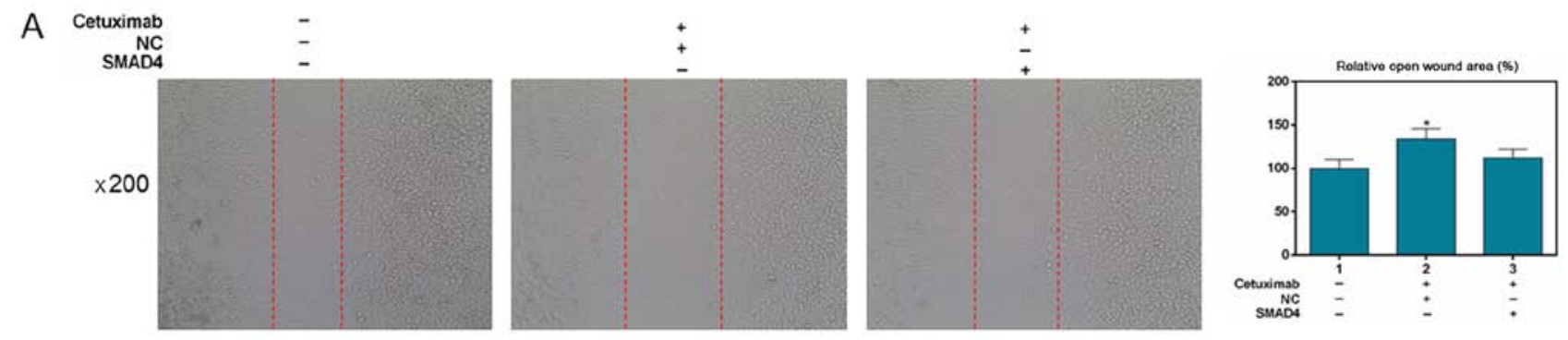

B
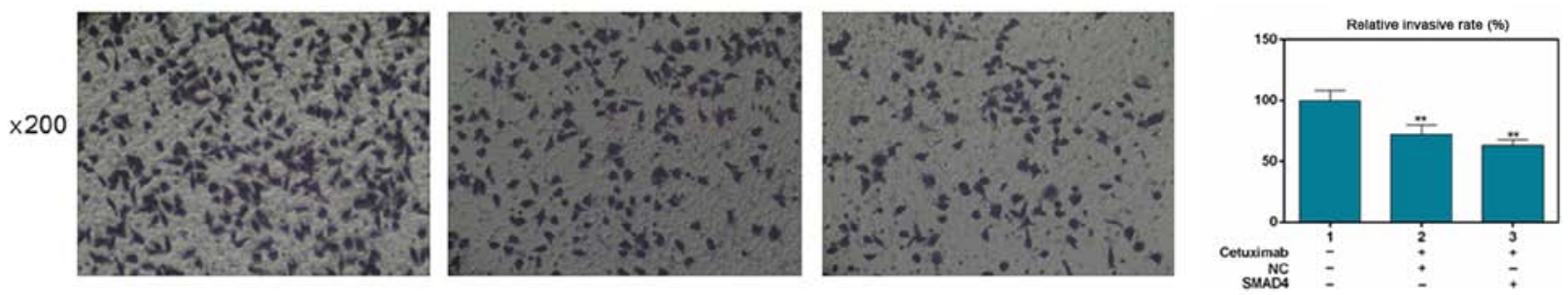

C
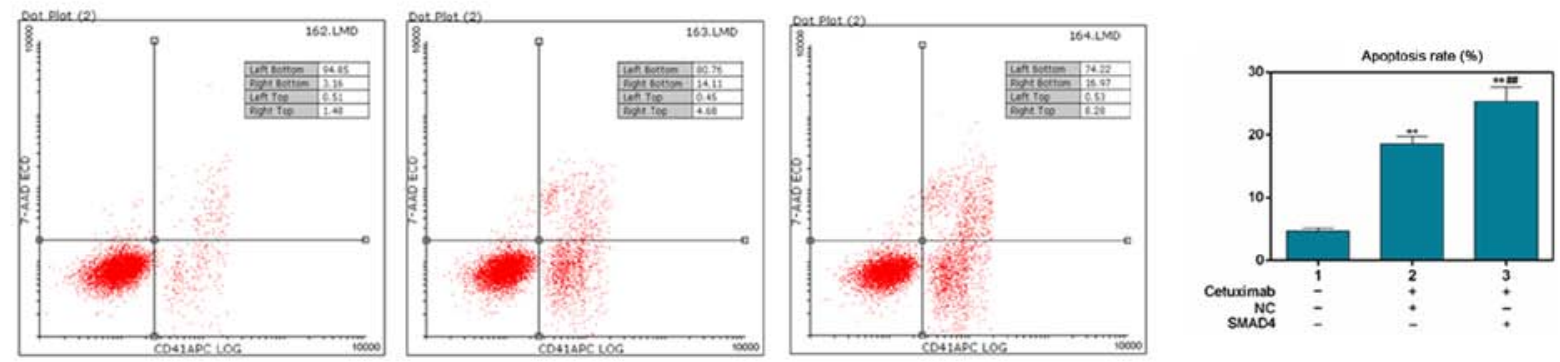

Figure 6. Smad4 overexpression affects migration, invasion and apoptosis of SW480 cells treated with cetuximab. (A) Cell migration was detected using scratch assay (x200 magnification; light microscopy). (B) Transwell assay was used to determine cell invasion (magnification, x200; light microscopy). (C) Apoptosis was detected by flow cytometry. ${ }^{*} \mathrm{P}<0.05$ and ${ }^{* *} \mathrm{P}<0.01$ vs. control; ${ }^{\# \#} \mathrm{P}<0.01$ vs. $\mathrm{NC}+$ cetuximab. $\mathrm{NC}$, negative control.
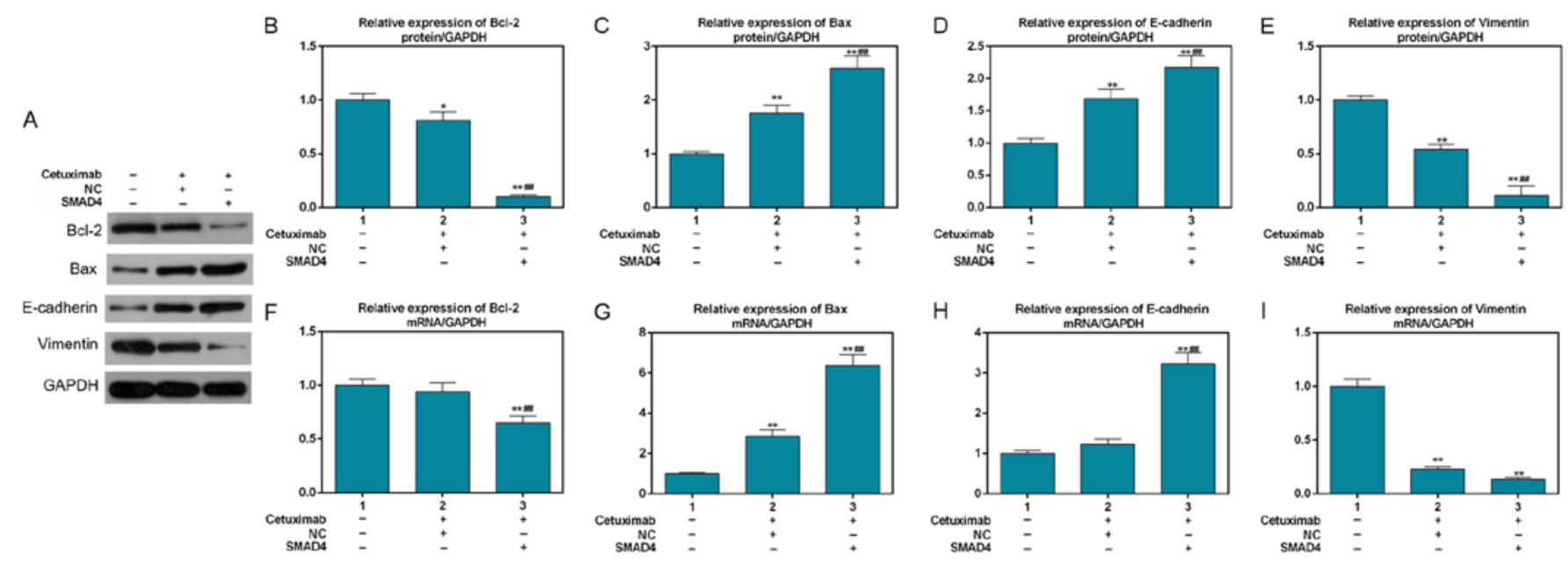

Figure 7. Smad4 overexpression affects the expression of apoptosis- and epithelial-mesenchymal transition-associated genes in SW480 cells treated with cetuximab. (A) Protein expression levels of Bcl-2, Bax, E-cadherin and vimentin were assessed using western blotting in SW480 cells with cetuximab treatment. Relative protein expression levels of (B) Bcl-2, (C) Bax, (D) E-cadherin and (E) vimentin were presented as histograms. mRNA expression levels of (F) Bcl-2, (G) Bax, (H) E-cadherin and (I) vimentin were assessed using reverse transcription-quantitative PCR in SW480 cells with cetuximab treatment; GAPDH served as an internal control. Data are expressed as the means \pm standard deviation from three independent experiments. ${ }^{*} \mathrm{P}<0.05$ and ${ }^{* * *} \mathrm{P}<0.01$ vs. control; ${ }^{\# \prime} \mathrm{P}<0.01$ vs. $\mathrm{NC}+$ cetuximab. NC, negative control.

Conversely, the sensitivity of SW480 cells to cetuximab was enhanced when SW480 cells were transfected with a plasmid overexpressing Smad4. The results indicated that the expression of Smad4 may serve a role in the response of SW480 cells to cetuximab. Previous studies have reported that downregulation of Smad4 is associated with a poor prognosis in response to 5-fluorouracil chemotherapy among patients with advanced CRC $(15,41)$. Evidence also demonstrated that Smad4 is associated with chemotherapy and radiotherapy resistance in cancer. For example, Smad4 knockdown promotes cetuximab resistance in head and neck squamous cell carcinoma by inducing mitogen-activated protein kinases/JNK activation $(42,43)$. 
Wang et al (44) suggested that Smad4 mutations are responsible for the resistance of pancreatic cancer to radiotherapy. Sun et al (45) also reported that microRNA-574 promotes doxorubicin resistance of MCF-7 cells by downregulating Smad4 in breast cancer cells.

A number of studies have reported that low expression of Smad4 is associated with EMT and poor prognosis of colon cancer (46-48). Therefore it was speculated that this may be the underlying mechanism by which Smad4 affects the sensitivity of SW480 CRC cells to cetuximab. In the present study, silencing Smad4 partly reversed the expression of E-cadherin increased by cetuximab and the expression of vimentin decreased by cetuximab. EMT commonly occurs in the heart or palate, and is associated with placentation (49-53). In recent years, EMT has been proposed to be involved in the invasion and metastasis of tumor cells (49). Accordingly, fibroblastoid or 'spindle-cell' tumors of epithelial origin have been characterized as highly malignant and invasive (54-56). E-cadherin is an important component of epithelial intercellular junctions and vimentin is an interstitial cell-specific protein; the two proteins are typical characteristic markers of EMT (57-60). Fuchs et al (61) suggested that EMT serves an important role in cetuximab resistance to hepatocellular carcinoma. Liu et al has also demonstrated that Smad4 is implicated with cancer cell resistance caused by EMT (62).

Studies of the definite mechanism underlying the effect rendered by Smad4 may also be beneficial. Various factors, including Wnt, Hedgehog and Notch signaling, may regulate the association between EMT and cancer cell resistance (63-65). However, there remain a number of shortcomings in the present study, including the lack of in vivo experiments. We aim to conduct a further detailed investigation into the association of Smad4 protein levels with E-cadherin or vimentin protein levels in CRC tissues or matched normal tissues, and also to perform validation experiments in one more cell line and in vivo mice models.

In conclusion, Smad4 may serve a vital role in the sensitivity of CRC cells to chemotherapy via EMT. Furthermore, a high expression of Smad4 may clinically benefit cetuximab-based treatment.

\section{Acknowledgements}

Not applicable.

\section{Funding}

The present study was supported by The National Key Clinical Specialist Construction Program of China; and Medical Innovation Project of Fujian Health Department (grant no. 2017-CX-29).

\section{Availability of data and materials}

The datasets used and/or analyzed during the current study are available from the corresponding author on reasonable request.

\section{Authors' contributions}

ZL made substantial contributions to conception and design; LZ, JZho and JZhe performed data acquisition, data analysis and interpretation. All authors drafted the article or critically revised it for important intellectual content and All authors approved the final version to be published. All authors agreed to be accountable for all aspects of the work in ensuring that questions related to the accuracy or integrity of the work were appropriately investigated and resolved:

\section{Ethics approval and consent to participate}

Not applicable.

\section{Patient consent for publication}

Not applicable.

\section{Competing interests}

The authors declare that they have no competing interests.

\section{References}

1. Ferlay J, Shin HR, Bray F, Forman D, Mathers C and Parkin DM: Estimates of worldwide burden of cancer in 2008: GLOBOCAN 2008. Int J Cancer 127: 2893-2917, 2010.

2. Siegel R, Naishadham D and Jemal A: Cancer statistics, 2013. CA Cancer J Clin 63: 11-30, 2013.

3. O'Connell MJ, Campbell ME, Goldberg RM, Grothey A, Seitz JF, Benedetti JK, André T, Haller DG and Sargent DJ: Survival following recurrence in stage II and III colon cancer: Findings from the ACCENT data set. J Clin Oncol 26: 2336-2341, 2008

4. Weitz J, Koch M, Debus J, Höhler T, Galle PR and Büchler MW: Colorectal cancer. Lancet 365: 153-165, 2005.

5. Van Cutsem E, Köhne CH, Láng I, Folprecht G, Nowacki MP, Cascinu S, Shchepotin I, Maurel J, Cunningham D, Tejpar S, et al: Cetuximab plus irinotecan, fluorouracil, and leucovorin as first-line treatment for metastatic colorectal cancer: Updated analysis of overall survival according to tumor KRAS and BRAF mutation status. J Clin Oncol 29: 2011-2019, 2011.

6. Meyerhardt JA and Mayer RJ: Systemic therapy for colorectal cancer. N Engl J Med 352: 476-487, 2005.

7. Cunningham D, Humblet Y, Siena S, Khayat D, Bleiberg H, Santoro A, Bets D, Mueser M, Harstrick A, Verslype C, et al: Cetuximab monotherapy and cetuximab plus irinotecan in irinotecan-refractory metastatic colorectal cancer. N Engl J Med 351: 337-345, 2004.

8. Misale S, Di Nicolantonio F, Sartore-Bianchi A, Siena S and Bardelli A: Resistance to anti-EGFR therapy in colorectal cancer: From heterogeneity to convergent evolution. Cancer Discov 4: 1269-1280, 2014

9. Bronte G, Silvestris N, Castiglia M, Galvano A, Passiglia F, Sortino G, Cicero G, Rolfo C, Peeters M, Bazan V, et al: New findings on primary and acquired resistance to anti-EGFR therapy in metastatic colorectal cancer: Do all roads lead to RAS? Oncotarget 6: 24780-24796, 2015.

10. Demagny H and De Robertis EM: Point mutations in the tumor suppressor Smad4/DPC4 enhance its phosphorylation by GSK3 and reversibly inactivate TGF- $\beta$ signaling. Mol Cell Oncol 3: e1025181, 2015.

11. Inamoto $\mathrm{S}$, Itatani $\mathrm{Y}$, Yamamoto $\mathrm{T}$, Minamiguchi $\mathrm{S}$, Hirai $\mathrm{H}$, Iwamoto M, Hasegawa S, Taketo MM, Sakai Y and Kawada K: Loss of SMAD4 promotes colorectal cancer progression by accumulation of myeloid-derived suppressor cells through the CCL15-CCR1 chemokine axis. Clin Cancer Res 22: 492-501, 2016.

12. Voorneveld PW, Kodach LL, Jacobs RJ, Liv N, Zonnevylle AC, Hoogenboom JP, Biemond I, Verspaget HW, Hommes DW, de Rooij K, et al: Loss of SMAD4 alters BMP signaling to promote colorectal cancer cell metastasis via activation of Rho and ROCK. Gastroenterology 147: 196-208.e113, 2014.

13. Liu L, Nie J, Chen L, Dong G, Du X, Wu X, Tang Y and Han W: The oncogenic role of microRNA-130a/301a/454 in human colorectal cancer via targeting Smad4 expression. PLoS One 8: e55532, 2013. 
14. Alazzouzi H, Alhopuro P, Salovaara R, Sammalkorpi H, Järvinen $\mathrm{H}$, Mecklin JP, Hemminki A, Schwartz S Jr, Aaltonen LA and Arango D: SMAD4 as a prognostic marker in colorectal cancer. Clin Cancer Res 11: 2606-2611, 2005.

15. Alhopuro P,Alazzouzi H,Sammalkorpi H,Dávalos V, Salovaara R, Hemminki A, Järvinen H, Mecklin JP, Schwartz S Jr, Aaltonen LA and Arango D: SMAD4 levels and response to 5-fluorouracil in colorectal cancer. Clin Cancer Res 11: 6311-6316, 2005.

16. Losi L, Bouzourene H and Benhattar J: Loss of Smad4 expression predicts liver metastasis in human colorectal cancer. Oncol Rep 17: 1095-1099, 2007.

17. Miyaki M, Iijima T, Konishi M, Sakai K, Ishii A, Yasuno M, Hishima T, Koike M, Shitara N, Iwama T, et al: Higher frequency of Smad4 gene mutation in human colorectal cancer with distant metastasis. Oncogene 18: 3098-3103, 1999.

18. Shintani Y, Okimura A, Sato K, Nakagiri T, Kadota Y, Inoue M, Sawabata N, Minami M, Ikeda N, Kawahara K, et al: Epithelial to mesenchymal transition is a determinant of sensitivity to chemoradiotherapy in non-small cell lung cancer. Ann Thorac Surg 92: 1794-1804, 2011.

19. Tomono T, Yano K and Ogihara T: Snail-induced epithelial-to-mesenchymal transition enhances P-gp-mediated multidrug resistance in HCC827 cells. J Pharm Sci 106 2642-2649, 2017

20. Shi Q, Diao Y, Jin F and Ding Z: Antimetastatic effects of Aidi on human esophageal squamous cell carcinoma by inhibiting epithelialmesenchymal transition and angiogenesis. Mol Med Rep 18: 131-138, 2018.

21. Zheng J, Zhang M, Zhang L, Ding X, Li W and Lu S: HSPC159 promotes proliferation and metastasis via inducing EMT and activating PI3K/Akt pathway in breast cancer. Cancer Sci 109: 2153-2163, 2018

22. Kalluri R: EMT: When epithelial cells decide to become mesenchymal-like cells. J Clin Invest 119: 1417-1419, 2009.

23. Greenburg G and Hay ED: Epithelia suspended in collagen gels can lose polarity and express characteristics of migrating mesenchymal cells. J Cell Biol 95: 333-339, 1982.

24. Brabletz T, Hlubek F, Spaderna S, Schmalhofer O Hiendlmeyer E, Jung A and Kirchner T: Invasion and metastasis in colorectal cancer: Epithelial-mesenchymal transition, mesenchymal-epithelial transition, stem cells and beta-catenin. Cells Tissues Organs 179: 56-65, 2005.

25. Polyak K and Weinberg RA: Transitions between epithelial and mesenchymal states: Acquisition of malignant and stem cell traits. Nat Rev Cancer 9: 265-273, 2009.

26. Moon SU, Kang MH, Sung JH, Kim JW, Lee JO, Kim YJ, Lee KW, Bang SM, Lee JS and Kim JH: Effect of Smad3/4 on chemotherapeutic drug sensitivity in colorectal cancer cells. Oncol Rep 33: 185-192, 2015

27. Zhang B, Zhang B, Chen X, Bae S, Singh K, Washington MK and Datta PK: Loss of Smad4 in colorectal cancer induces resistance to 5-fluorouracil through activating Akt pathway. Br J Cancer 110: 946-957, 2014.

28. Papageorgis P, Cheng K, Ozturk S, Gong Y, Lambert AW, Abdolmaleky HM, Zhou JR and Thiagalingam S: Smad4 inactivation promotes malignancy and drug resistance of colon cancer. Cancer Res 71: 998-1008, 2011.

29. Sun C, Wang FJ, Zhang HG, Xu XZ, Jia RC, Yao L and Qiao PF: miR-34a mediates oxaliplatin resistance of colorectal cancer cells by inhibiting macroautophagy via transforming growth factor- $\beta /$ Smad4 pathway. World J Gastroenterol 23: 1816-1827, 2017.

30. Livak KJ and Schmittgen TD: Analysis of relative gene expression data using real-time quantitative PCR and the 2(-Delta Delta C(T)) method. Methods 25: 402-408, 2001

31. Zhao S, Venkatasubbarao K, Lazor JW, Sperry J, Jin C, Cao L and Freeman JW: Inhibition of STAT3 Tyr705 phosphorylation by Smad4 suppresses transforming growth factor beta-mediated invasion and metastasis in pancreatic cancer cells. Cancer Res 68: 4221-4228, 2008.

32. Wang H, Rajan S, Liu G and Chakrabarty S: Transforming growth factor beta suppresses beta-catenin/Wnt signaling and stimulates an adhesion response in human colon carcinoma cells in a Smad4/DPC4 independent manner. Cancer Lett 264: 281-287, 2008

33. Barros R, Pereira B, Duluc I, Azevedo M, Mendes N, Camilo V, Jacobs RJ, Paulo P, Santos-Silva F, van Seuningen I, et al: Key elements of the BMP/SMAD pathway co-localize with CDX2 in intestinal metaplasia and regulate CDX2 expression in human gastric cell lines. J Pathol 215: 411-420, 2008.
34. Huang S, Zhang F, Miao L, Zhang H, Fan Z, Wang X and Ji G: Lentiviral-mediated Smad4 RNAi induced anti-proliferation by p16 up-regulation and apoptosis by caspase 3 down-regulation in hepatoma SMMC-7721 cells. Oncol Rep 20: 1053-1059, 2008.

35. Druliner BR, Ruan X, Sicotte H, O'Brien D, Liu H, Kocher JA and Boardman L: Early genetic aberrations in patients with sporadic colorectal cancer. Mol Carcinog 57: 114-124, 2018.

36. Al-Shamsi HO, Jones J, Fahmawi Y, Dahbour I, Tabash A, Abdel-Wahab R, Abousamra AO, Shaw KR, Xiao L, Hassan MM, et al: Molecular spectrum of KRAS, NRAS, BRAF, PIK3CA, TP53, and APC somatic gene mutations in Arab patients with colorectal cancer: Determination of frequency and distribution pattern. J Gastrointest Oncol 7: 882-902, 2016.

37. Müller MF, Ibrahim AE and Arends MJ: Molecular pathological classification of colorectal cancer. Virchows Arch 469: 125-134, 2016.

38. Mehrvarz Sarshekeh A, Advani S, Overman MJ, Manyam G, Kee BK, Fogelman DR, Dasari A, Raghav K, Vilar E, Manuel S, et al: Association of SMAD4 mutation with patient demographics, tumor characteristics, and clinical outcomes in colorectal cancer. PLoS One 12: e0173345, 2017.

39. Wang C, Zhou Y, Ruan R, Zheng M, Han W and Liao L: High expression of COUP-TF II cooperated with negative Smad4 expression predicts poor prognosis in patients with colorectal cancer. Int J Clin Exp Pathol 8: 7112-7121, 2015.

40. Mei Z, Shao YW, Lin P, Cai X, Wang B, Ding Y, Ma X, Wu X, Xia Y, Zhu D, et al: SMAD4 and NF1 mutations as potential biomarkers for poor prognosis to cetuximab-based therapy in Chinese metastatic colorectal cancer patients. BMC Cancer 18: 479, 2018.

41. Zhang B, Leng C, Wu C, Zhang Z, Dou L, Luo X, Zhang B and Chen X: Smad4 sensitizes colorectal cancer to 5-fluorouracil through cellcycle arrest by inhibiting the PI3K/Akt/CDC2/survivin cascade. Oncol Rep 35: 1807-1815, 2016.

42. Ozawa H, Ranaweera RS, Izumchenko E, Makarev E, Zhavoronkov A, Fertig EJ, Howard JD, Markovic A, Bedi A, Ravi R, et al: SMAD4 loss is associated with cetuximab resistance and induction of MAPK/JNK activation in head and neck cancer cells. Clin Cancer Res 23: 5162-5175, 2017.

43. Cheng H, Fertig EJ, Ozawa H, Hatakeyama H, Howard JD, Perez J, Considine M, Thakar M, Ranaweera R, Krigsfeld G and Chung CH: Decreased SMAD4 expression is associated with induction of epithelial-to-mesenchymal transition and cetuximab resistance in head and neck squamous cell carcinoma. Cancer Biol Ther 16: 1252-1258, 2015

44. Wang F, Xia X, Yang C, Shen J, Mai J, Kim HC, Kirui D, Kang Y, Fleming JB, Koay EJ, et al: SMAD4 gene mutation renders pancreatic cancer resistance to radiotherapy through promotion of autophagy. Clin Cancer Res 24: 3176-3185, 2018.

45. Sun FD, Wang PC, Luan RL, Zou SH and Du X: MicroRNA-574 enhances doxorubicin resistance through down-regulating SMAD4 in breast cancer cells. Eur Rev Med Pharmacol Sci 22: 1342-1350, 2018

46. Shiou SR, Singh AB, Moorthy K, Datta PK, Washington MK, Beauchamp RD and Dhawan P: Smad4 regulates claudin-1 expression in a transforming growth factor-beta-independent manner in colon cancer cells. Cancer Res 67: 1571-1579, 2007.

47. Xiao DS, Wen JF, Li JH, Hu ZL, Zheng H and Fu CY: Effect of deleted pancreatic cancer locus 4 gene transfection on biological behaviors of human colorectal carcinoma cells. World J Gastroenterol 11: 348-352, 2005

48. Liu SQ, Xu CY, Wu WH, Fu ZH, He SW, Qin MB and Huang JA: Sphingosine kinase 1 promotes the metastasis of colorectal cancer by inducing the epithelialmesenchymal transition mediated by the FAK/AKT/MMPs axis. Int J Oncol 54: 41-52, 2019.

49. Thiery JP and Chopin D: Epithelial cell plasticity in development and tumor progression. Cancer Metastasis Rev 18: 31-42, 1999.

50. Potts JD and Runyan RB: Epithelial-mesenchymal cell transformation in the embryonic heart can be mediated, in part, by transforming growth factor beta. Dev Biol 134: 392-401, 1989.

51. Brown CB, Boyer AS, Runyan RB and Barnett JV: Requirement of type III TGF-beta receptor for endocardial cell transformation in the heart. Science 283: 2080-2082, 1999.

52. Proetzel G, Pawlowski SA, Wiles MV, Yin M, Boivin GP Howles PN, Ding J, Ferguson MW and Doetschman T: Transforming growth factor-beta 3 is required for secondary palate fusion. Nat Genet 11: 409-414, 1995.

53. Kaartinen V, Voncken JW, Shuler C, Warburton D, Bu D, Heisterkamp N and Groffen J: Abnormal lung development and cleft palate in mice lacking TGF-beta 3 indicates defects of epithelial-mesenchymal interaction. Nat Genet 11: 415-421, 1995. 
54. Oft M, Peli J, Rudaz C, Schwarz H, Beug H and Reichmann E: TGF-beta1 and Ha-Ras collaborate in modulating the phenotypic plasticity and invasiveness of epithelial tumor cells. Genes Dev 10: 2462-2477, 1996.

55. Battifora H: Spindle cell carcinoma: Ultrastructural evidence of squamous origin and collagen production by the tumor cells. Cancer 37: 2275-2282, 1976.

56. Buchmann A, Ruggeri B, Klein-Szanto AJ and Balmain A: Progression of squamous carcinoma cells to spindle carcinomas of mouse skin is associated with an imbalance of $\mathrm{H}$-ras alleles on chromosome 7. Cancer Res 51: 4097-4101, 1991.

57. Geiger T, Sabanay H, Kravchenko-Balasha N, Geiger B and Levitzki A: Anomalous features of EMT during keratinocyte transformation. PLoS One 3: e1574, 2008.

58. Huber MA, Kraut N and Beug H: Molecular requirements for epithelial-mesenchymal transition during tumor progression. Curr Opin Cell Biol 17: 548-558, 2005.

59. Larue L and Bellacosa A: Epithelial-mesenchymal transition in development and cancer: Role of phosphatidylinositol $3^{\prime}$ kinase/AKT pathways. Oncogene 24: 7443-7454, 2005.

60. Thompson EW, Newgreen DF and Tarin D: Carcinoma invasion and metastasis: A role for epithelial-mesenchymal transition? Cancer Res 65: 5991-5995, 2005.

61. Fuchs BC, Fujii T, Dorfman JD, Goodwin JM, Zhu AX, Lanuti M and Tanabe KK: Epithelial-to-mesenchymal transition and integrin-linked kinase mediate sensitivity to epidermal growth factor receptor inhibition in human hepatoma cells. Cancer Res 68: 2391-2399, 2008.
62. Liu Y, Li Y, Wang R, Qin S, Liu J, Su F, Yang Y, Zhao F, Wang Z and $\mathrm{Wu} \mathrm{Q}: \mathrm{MiR}-130 \mathrm{a}-3 \mathrm{p}$ regulates cell migration and invasion via inhibition of Smad4 in gemcitabine resistant hepatoma cells. J Exp Clin Cancer Res 35: 19, 2016.

63. Wen Z, Feng S, Wei L, Wang Z, Hong D and Wang Q: Evodiamine, a novel inhibitor of the Wnt pathway, inhibits the self-renewal of gastric cancer stem cells. Int J Mol Med 36: 1657-1663, 2015.

64. Della Corte CM, Bellevicine C, Vicidomini G, Vitagliano D, Malapelle U, Accardo M, Fabozzi A, Fiorelli A, Fasano M, Papaccio F, et al: SMO gene amplification and activation of the hedgehog pathway as novel mechanisms of resistance to anti-epidermal growth factor receptor drugs in human lung cancer. Clin Cancer Res 21: 4686-4697, 2015.

65. Güngör C, Zander H, Effenberger KE, Vashist YK, Kalinina T, Izbicki JR, Yekebas E and Bockhorn M: Notch signaling activated by replication stress-induced expression of midkine drives epithelial-mesenchymal transition and chemoresistance in pancreatic cancer. Cancer Res 71: 5009-5019, 2011.

This work is licensed under a Creative Commons Attribution-NonCommercial-NoDerivatives 4.0 International (CC BY-NC-ND 4.0) License. 